\title{
Protein C, protein S, antithrombin III, and hyperfibrinogenemia in deep vein thrombosis (DVT) among patients who underwent high risk orthopaedic surgery
}

\author{
Ismail $^{\#}$, D.A.L. Tobing ${ }^{\#}$, A. Bachtiar ${ }^{f}$, U.P. Siregar ${ }^{\#}$, K.L. Tambunan ${ }^{\theta}$
}

\begin{abstract}
Abstrak
Kasus trombosis vena dalam (TVD) pasca operasi di Indonesia dianggap jarang, demikian pula dengan trombofilia. Oleh karena itu, penulis berpendapat bahwa diperlukan penelitian untuk mendapat angka kejadian TVD pasca operasi ortopedi risiko tinggi, dan profil trombofilia pada kasus TVD dan non-TVD di Indonesia. Penelitian cross sectional ini dilakukan pada 20 pasien yang menjalani operasi daerah panggul (total hip replacement dan fiksasi fraktur femur proksimal) dan daerah lutut (fiksasi femur distal dan total knee replacement). Pada tiap pasien dilakukan pemeriksaan protein $C$, protein $S$, antitrombin III, dan fibrinogen pada hari kelima pasca operasi, kemudian pada periode antara hari kesepuluh dan keduapuluhsatu pasca operasi dilakukan pemeriksaan USG kompresi/Doppler vena. Bila hasil USG-nya menunjukkan adanya TVD, maka dikonfirmasi dengan venografi. TVD ditemukan pada lima pasien (25\%). Defisiensi protein $C(P=0,46)$, protein $S(P=0,81)$, antitrombin III $(P=0,46)$, dan hiperfibrinogenemia $(P=0,0547)$ tidak berkorelasi dengan TVD pasca operasi. Namun demikian, hiperfibrinogenemia merupakan faktor risiko TVD pasca operasi (attributable risk=1). Faktor penyerta lain seperti diabetes mellitus $(P=1,0)$, obesitas $(P=0,28)$, hipertensi $(P=1,0)$, hipertrigliseridemia, dan hiperkolesterolemia tidak berkorelasi dengan TVD pasca operasi. Penelitian ini menunjukkan adanya kasus TVD pasca operasi di Indonesia. TVD tidak berkorelasi dengan defisiensi protein S, protein C, dan antitrombin III. (Med J Indones 2004; 13: 24-30)
\end{abstract}

\begin{abstract}
Post operative DVT is believed to be rare in Indonesia, and so is trombophilia. It is necessary to know the incidence of postoperative DVT in Indonesia and thrombophlia profile (protein $C$, S, AT III deficiency and hyperfibrinogenemia) in DVT and non DVT patient who underwent orthopedic surgery involving the hip and knee (high risk surgery). A cross sectional study was conducted in 20 patients who underwent surgery involving the hip (total hip replacement and fixation of proximal femoral fracture) and knee (total knee replacement and fixation of distal femoral fracture). Protein $C$, protein $S$, antithrombin III, and fibrinogen were examined in day 5 post operative, as well as with compression/Doppler USG between day 10 to 21 post operative, and confirmed by venography if USG findings was positive. Post operative DVT were found in 5 of 20 patients $(25 \%)$. Deficiency of protein $C(P=0.46)$ protein $S(P=0.81)$, antithrombin III $(P=$ $0.46)$, and hyperfibrinogenemia $(P=0.0547)$ did not correlate to post operative DVT. However, hyperfibrinogenemia was found to be a risk factor to post operative DVT (attributable risk=1). Other confounding factor such as diabetes mellitus $(P=1.0)$, obesity $(P=0.28)$, hypertention $(P=1.0)$, hypertrigliseridemia, and hypercholesterolemia did not correlate to post operative DVT. The study suggested the existence of postoperative DVT cases in Indonesia. Hyperfibrinogenemia is a risk factor to promote post operative DVT. Deep vein thrombosis did not correlate to protein $S$, protein $C$, and antithrombin III deficiency. (Med J Indones 2004; 13: 24-30)
\end{abstract}

Keywords: Thrombophilia, hip, knee, venography

\footnotetext{
\# Department of Surgery, Division of Orthopaedics and Traumatology, Faculty of Medicine, University of Indonesia / Dr. Cipto Mangunkusumo Hospital, Jakarta, Indonesia

${ }^{\theta}$ Department of Internal Medicine, Faculty of Medicine, University of Indonesia / Dr. Cipto Mangunkusumo Hospital, Jakarta, Indonesia

${ }^{f}$ Faculty of Public Health, University of Indonesia, Jakarta, Indonesia
}

Deep vein thrombosis (DVT) is a major complication found in orthopedic surgery, patients with cancer or other chronic illness. Patients who survive the initial episode of DVT are prone to chronic swelling and pain of the leg because the valves in the veins can be damaged by the thrombotic process, leading to venous hypertension. In some instances skin ulceration and impaired mobility prevent patients from having normal activities. In addition, patient with DVT are 
prone to recurrent episodes and development of pulmonary embolism (PE). When DVT and PE developes as complications of surgical or medical illness, mortality risk increases. In addition, hospitalization is prolonged and health care cost are increased. ${ }^{1}$

DVT is a condition which thrombus is formed in the deep vein especially in the lower extremity and groin. The formation, growth, and dissolution of venous thrombi and PE reflect a balance between the effects of thrombotic stimuli and a variety of protective mechanisms. ${ }^{2}$ The factors, that influence the balance and implicate the pathogenesis of venous thrombosis, are known as the Virchow Triad, ${ }^{1,3-5}$ which are :

1. activation of blood coagulation (hypercoagulability)

2. venous stasis

3. vascular injury (endothelial damage)

Of the three causative factors of DVT, the most important one are venous stasis and hypercoagulability. ${ }^{6}$ Thrombophilia is an increased tendency to thrombosis (alteration of blood condition that lead to venous thrombosis). The alteration consists of increased normal activation of coagulation factor, decreased circulating inhibitor level, disturbance of fibrinolytic system function, and hyperactive thrombocytes. ${ }^{7}$ Hypercoagulability and stasis cooperate to form venous thrombosis.

Improvement in diagnostic test of homeostasis, provides clearer understanding of hypercoagulability. Fifty to eighty percent of the causes is based on thrombocyte defect or inherited or acquired abnormality in proteins involved in coagulation. ${ }^{1}$ Deficiency of protein C, protein S, antithrombin III, activated protein C (APC) resistance, and hyperfibrinogenemia are important factor of hypercoagulability. Activated protein $\mathrm{C}$ resistance is the cause of $10-64 \%$ of cases with hypercoagulability. ${ }^{8}$ However, mutation and APC resistance is very rare in Asian population, and a chromosome study of 105 samples in Indonesia which were taken in Sumatra did not found, either heterozygote or homozygote abnormalities. ${ }^{9}$

Under normal condition, antithrombin III (AT III), protein $\mathrm{C}$ and protein $\mathrm{S}$ (an active protein $\mathrm{C}$ co factor) are natural anti coagulants (hemostatic control) that balance procoagulation activitiy and cause thrombinantithrombin complex balance to prevent thrombosis. If the condition of natural anticoagulants and procoagulants becomes unbalanced, it can lead to thrombosis. ${ }^{10}$ Fibrinogen promote fibrin formation, platelet aggregation, and plasma viscosity. ${ }^{11}$
Surgery involving the hip (such as total hip replacement [THR] and fixation of the proximal femoral fracture) and the knee (total knee replacement [TKR] and fixation of the distal femoral fracture) are DVT high risk orthopedic proceedures. Deep vein thrombosis formation has started since the start of surgery, but generally thrombus was formed in day 3 to 7 post operative. ${ }^{12}$ Local venous injury and stasis play a role in leading to thrombosis in orthopedic patients. ${ }^{13}$

Management of DVT is divided into thromboprophylaxis and treatment. Thromboprophylaxis is directed to the patients with DVT risk. Treatment is directed to the patients who objectively have been diagnosed as having DVT. ${ }^{13}$ However, protocol of prophylactic treatment of high risk orthopedic surgery has not been applied in Indonesia.

In the past, it was believed that the incidence of DVT in Asia was rare. A study on post operative patients found that DVT incidence rate in Malaysia was equal to Western country population. In the study, incidence of post operative DVT on total knee replacement is $76.5 \%$, total hip replacement is $64.3 \%$ and fixation of proximal femoral fracture is $50 \%{ }^{14}$ A study in 5 major hospitals in Metro Manila that included 515 patients who underwent major hip and knee surgery without prophylaxis showed an ultrasonographic incidence of $12 \% .{ }^{15}$ Data of post orthopedic surgery DVT in Indonesia has never been established and reported yet.

Post operative DVT cases in Indonesia are believed to be rare and either are the thrombophilia, deficiency of protein $\mathrm{C}$, protein $\mathrm{S}$, and antithrombin III. Hyperfibrinogenemia is an important factor of thrombophilia or hypercoagulable state. Therefore, this study aims to know the incidence of post operative DVT in Indonesia, and to compare thrombophilia (protein $\mathrm{S}$, $\mathrm{C}$, and AT III deficiency and hyperfibrinogenemia) in DVT and non DVT patients who underwent orthopedic surgery involving the hip and knee.

\section{METHODS}

This was a cross sectional observational study, that observed the level of protein C, S, antithrombin III (AT III), and fibrinogen in DVT and non DVT patients who underwent surgery involving the hip (THR and fixation of the proximal femoral fracture), and the knee (TKR and fixation of the distal femoral 
fracture), during the period of June 2001 until September 2002, in Ciptomangunkusumo, Fatmawati, St Carollus, and Cikini hospital in Jakarta.

Protein $\mathrm{C}$, protein S, AT III and fibrinogen were examined in day 5 post operative, and thrombosis was assessed using compression/Doppler USG between day 10 to 21 post operative day, and confirmed by venography, if USG findings was positive.

Deficiency of protein S, protein C and AT III was regarded as positive when the level of activity is below $70 \%, 70 \%$, and $75 \%$ of the normal range respectively, and negative when it is within normal range. Hyperfibrinogenemia was regarded positive when the level of fibrinogen was above $350 \mathrm{mg} / \mathrm{dl}$.

Positive DVT was diagnosed when in venography an intraluminal filling defect was present at least in two projection. Negative DVT was diagnosed when blood clot or thrombosis was not found in deep vein in inguinal and lower leg by compression/Doppler USG.

The data were analysed using Stata 6 by Fisher's exact test (exact $P$ value, relative risk and confidence interval) to know the correlation between deficiency of protein S, C, AT III, and hyperfibrinogenemia with DVT with $\alpha=0.05$. Correlation of influencing factors such as diabetes mellitus, hypertension, obesity, and post operative DVT was also tested.

\section{RESULTS}

During June 2001 through September 2002, 20 patients were enrolled in this study. The age range of the patients were 35 to 84 years with an average of 68 years. Most samples were female $(70 \%)$, and older ones. Patient below 40 years was 5\%, 40-60 years was $25 \%$, and more than 60 years was $70 \%$. Type of operation were operation involving the hip (85\%), that were THR and proximal femoral fixation, and operation involving the knee (15\%), that were TKR and distal femoral fixation. The most operation performed was proximal femoral fixation (75\%).
The type of surgery for proximal femoral fracture fixation were 10 hemiarthroplasty (AMP), 3 dynamic hip screw (DHS), and 2 periarticular plate. Unfortunately, the number of cases underwent THR and TKR were very limited, due to the high cost of the procedure.

In this study, 5 of the 20 patients show signs of post orthopedic surgery DVT (25\%). The 5 patients underwent either hemiarthroplasty (AMP), proximal femoral fixation with periarticular plate, distal femoral fixation with condylar blade plate, THR, or TKR. The diagnosis of DVT were based on compression/Doppler USG and venography. Unfortunately, 1 patient post periarticular plate fixation refused to be confirmed by venography. However, clinically and by doppler USG the patient showed DVT. Therefore, the patient underwent heparin therapy, and good progression was noted cliinically.

Table 1 showed that there was no difference in the number of patients with protein S, protein C, or AT III deficiency, as well as fibrinogenemia, between male and female, between patients with age less and more than 60 years, and between patients with below normal, normal and more than normal body mass index [BMI].

Table 2 showed that there was no difference in the relative risk in developing DVT, between males and females, between age groups, between groups of below normal, compared to normal and more than normal BMI, and between types of surgery. However, DVT occurs in 5 of 20 patients (25\%), that had hip $(17.6 \%)$ and knee $(66.67 \%)$ surgery.

Table 2 also showed no correlation between protein $\mathrm{S}$ $(P=0.81)$, protein $\mathrm{C}(P=0.46)$, AT III deficiency $(P=$ $0.46)$, and hyperfibrinogenemia $(P=0.057)$ with DVT. However, attributable risk of hyperfibrinogenemia to DVT was high $(=1)$. There was no correlation between DVT and other influencing factors, such as hypertension $(P=1.0)$, diabetes mellitus $(P=1.0)$, hypertrigliseridemia, and hypercholestrolemia. 
Table 1. Sample characteristics: deficiency of AT-III, protein C, protein S, and hyperfibrinogenemia status in different gender, age, and BMI

\begin{tabular}{|c|c|c|c|c|c|c|c|}
\hline & & \multicolumn{2}{|c|}{ Gender } & \multicolumn{2}{|c|}{ Age } & \multicolumn{2}{|c|}{ BMI } \\
\hline & & $\mathrm{M}$ & $\mathrm{F}$ & $<60$ & $\geq 60$ & $<\mathrm{N}$ & $\geq \mathrm{N}$ \\
\hline \multirow[t]{2}{*}{ AT-III deficient } & Yes & 4 & 3 & 1 & 6 & 6 & 1 \\
\hline & No & 2 & 11 & 5 & 8 & 11 & 2 \\
\hline \multicolumn{2}{|l|}{ Exact $P$ (2-sided) } & \multicolumn{2}{|c|}{0.122} & \multicolumn{2}{|c|}{0.534} & \multicolumn{2}{|c|}{1.0} \\
\hline & & \multicolumn{2}{|c|}{ Gender } & \multicolumn{2}{|c|}{ Age } & \multicolumn{2}{|c|}{ BMI } \\
\hline & & $\mathrm{M}$ & $\mathrm{F}$ & $<60$ & $\geq 60$ & $<\mathrm{N}$ & $\geq \mathrm{N}$ \\
\hline \multirow[t]{2}{*}{ Protein $\mathrm{C}$ deficient } & Yes & 4 & 3 & 1 & 6 & 6 & 1 \\
\hline & No & 2 & 11 & 5 & 8 & 11 & 2 \\
\hline \multicolumn{2}{|l|}{ Exact $P$ (2-sided) } & \multicolumn{2}{|c|}{0.122} & \multicolumn{2}{|c|}{0.354} & \multicolumn{2}{|c|}{1.0} \\
\hline & & \multicolumn{2}{|c|}{ Gender } & \multicolumn{2}{|c|}{ Age } & \multicolumn{2}{|c|}{ BMI } \\
\hline & & $\mathrm{M}$ & $\mathrm{F}$ & $<60$ & $\geq 60$ & $<\mathrm{N}$ & $\geq \mathrm{N}$ \\
\hline \multirow[t]{2}{*}{ Protein $\mathrm{S}$ deficient } & Yes & 4 & 9 & 4 & 8 & 10 & 3 \\
\hline & No & 2 & 5 & 2 & 6 & 7 & 0 \\
\hline \multicolumn{2}{|l|}{ Exact $P(2$-sided $)$} & \multicolumn{2}{|c|}{1.0} & \multicolumn{2}{|c|}{1.0} & \multicolumn{2}{|c|}{0.521} \\
\hline & & \multicolumn{2}{|c|}{ Gender } & \multicolumn{2}{|c|}{ Age } & \multicolumn{2}{|c|}{ BMI } \\
\hline & & $\mathrm{M}$ & $3 \mathrm{~F}$ & $<60$ & $\geq 60$ & $<\mathrm{N}$ & $\geq \mathrm{N}$ \\
\hline \multirow[t]{2}{*}{ Hyperfibrinogenemia } & Yes & 4 & 8 & 5 & 7 & 9 & 3 \\
\hline & No & 2 & 6 & 2 & 6 & 8 & 0 \\
\hline \multicolumn{2}{|l|}{ Exact $P$ (2-sided) } & \multicolumn{2}{|c|}{1.0} & \multicolumn{2}{|c|}{0.642} & \multicolumn{2}{|c|}{0.242} \\
\hline & & \multicolumn{2}{|c|}{ Gender } & & & & \\
\hline & & $\mathrm{M}$ & $\mathrm{F}$ & $<60$ & $\geq 60$ & $<\mathrm{N}$ & $\geq \mathrm{N}$ \\
\hline Operation involving & Hip & 6 & 11 & 5 & 12 & 15 & 2 \\
\hline & Knee & 0 & 3 & 1 & 2 & 1 & 2 \\
\hline Exact $P(2$-sided $)$ & & & & & & & \\
\hline
\end{tabular}

Table 2. Bivariate analysis for relative risk of DVT according to gender, age, BMI, type of operation, deficiency in AT-III, protein C, protein S, and hyperfibrinogenemia status

\begin{tabular}{|c|c|c|c|c|c|}
\hline & & \multicolumn{2}{|c|}{ DVT } & \multirow[b]{2}{*}{ RR } & \multirow[b]{2}{*}{$95 \% \mathrm{CI}$} \\
\hline & & Yes & No & & \\
\hline \multirow[t]{2}{*}{ Gender } & Female & 2 & 12 & 1 & (reference) \\
\hline & Male & 3 & 3 & 3.5 & $0.79-15.53$ \\
\hline \multirow[t]{2}{*}{ Age } & $<60$ & 2 & 4 & 1 & (reference) \\
\hline & $\geq 60$ & 3 & 11 & 0.64 & $0.13-3.11$ \\
\hline \multirow[t]{2}{*}{ BMI } & $\leq \mathrm{N}$ & 3 & 14 & 1 & (reference) \\
\hline & $>\mathrm{N}$ & 2 & 1 & 3.78 & $0.86-16.57$ \\
\hline \multirow[t]{2}{*}{ Operation involving } & Hip & 3 & 14 & 1 & (reference) \\
\hline & Knee & 2 & 1 & 3.78 & $0.86-16.57$ \\
\hline \multirow[t]{2}{*}{ AT-III deficient } & No & 4 & 9 & 1 & (reference) \\
\hline & Yes & 1 & 6 & 0.46 & $0.07-3.10$ \\
\hline \multirow[t]{2}{*}{ Protein $\mathrm{C}$ deficient } & No & 4 & 9 & 1 & (reference) \\
\hline & Yes & 1 & 6 & 0.46 & $0.07-3.10$ \\
\hline \multirow[t]{2}{*}{ Protein S deficient } & No & 2 & 5 & 1 & (reference) \\
\hline & Yes & 3 & 10 & 0.81 & $0.16-3.95$ \\
\hline \multirow[t]{2}{*}{ Hyperfibrinogenemia } & No & 0 & 8 & 1 & (reference) \\
\hline & Yes & 5 & 7 & *) & $*)$ \\
\hline
\end{tabular}

*) Result overflow because divided by zero, white on 2-sided Fisher's exact $P=0.0547$ (not significant different) 


\section{DISCUSSION}

In this study, there were 5 patients with post operative DVT and 15 patients without DVT. However, the sample of this study did not represent population of post orthopedic surgery on the hip and knee perfectly, as for $\propto=0.05$, at least 82 samples are needed. Furthermore, ideally venography confirmation should be performed bilaterally. These facts were due to the limited time and budget. Therefore to get the accurate incidence of post operative DVT in Indonesia, further epidemiological studies with adequate number of cases are needed.

Surgery involving the hip and knee area were DVT high risk in orthopedic surgery, ${ }^{12}$ due to venous stasis, twisting and folding of femoral veins, surgical manipulations, increase in thromboplastin antigens, and heat generation during methacrilate polymerization. 9.16

Venous stasis began at the moment the patient was anesthetized and the tourniquet was inflated. Venous capacitance of the lower extremity veins has been shown to decrease post operatively, with an increasing potential for venous pooling and subsequent clotting. During dislocation of the hip, twisting and folding of femoral veins may distend and break the endothelial intercellular bridges, endothelial intercellular bridges, exposing collagen and other procoagulant substance to the circulatory system. Furthermore, retractor and surgical manipulations may cause extensive venous endothelial damage (ie. the use of posterior tibial retractor in knee arthroplasty), and heat generated during the polymerization of methacrilate may also cause some venous endothelial damage. These factors may be aggravated by a large increase in thromboplastin antigens that have been observed in reaming preparation of bone, and impacting various implant.

In this study, there was no significant difference in DVT formation, between surgery procedure involving the hip and knee. This fact was different from other studies that revealed that the incidence of DVT in knee area were higher than in the hip area. Without thromboprophylaxis, approximately $40-50 \%$ of patients with hip arthroplasty and 50-70\% with knee arthroplasty developed venographically confirmed DVT. ${ }^{13}$ This difference was due to the sample number that was larger in hip than knee surgery.

Thrombophilia factors: deficiency of protein C, S, antithrombin III, and hyperfibrinogenemia were not influenced by gender, age, and nutrition. This was shown by table 1 . Thrombophilia was caused by activated protein C (APC) resistance (10-16.4\%), deficiency of protein $\mathrm{S}(1.4-7.5 \%)$, deficiency of protein C (1.4-8.6\%), deficiency of AT III (0.5-4.9), prothrombin 20210A (5-7\%), and hyperfibrinogenemia. ${ }^{17}$ However, factor $\mathrm{V}$ Leiden that promote more than $95 \%$ of the cases of APC resistance and prothrombin 20210A can not be evaluated in Indonesia.

Protein C, a vitamin K-dependent plasma protein, is the key component in physiologically important anticoagulant system. After protein $\mathrm{C}$ activation on the surface of endothelial cell by a complex of thrombin and thrombomudulin, activated protein $\mathrm{C}$ (APC) inhibits coagulation by selectively degrading coagulation factors $\mathrm{Va}$ and VIIIa. ${ }^{18}$ Protein $\mathrm{C}$ deficiency is commonly classified in two types. Type I is characterized by reduced antigenic levels and functional activity in degrading activated factor $\mathrm{Vc}$ and VIIIc. Type II is characterized by normal antigen levels with reduced functional activity in degrading activated factor $\mathrm{Vc}$ and VIIIc. ${ }^{10}$

In homeostasis, protein $\mathrm{S}$ is a cofactor of the anticoagulant effect of protein C. Sixty percent of protein $\mathrm{S}$ is bound to C4B-binding protein in circulation, while the remainder were free (unbound) or bound to protein C. Low level activity of protein S may or may not involve protein $\mathrm{S}$ binding to protein $\mathrm{C} .{ }^{10}$

In the final phase of clot formation, thrombin convert fibrinogen to fibrin. The AT III, named for its action on thrombin, also inhibits the serine proteases of factor IXa, Xa, XIa, and XIIa. The AT III is inherited in an autosomal dominant fashion with an estimated frequency of 1 in 2,000. ${ }^{8}$ The AT III deficiency is divided in three types, type I: quantitative deficiency; type II: qualitative abnormal ability to inactivate factor Xa and thrombin, and type III: due to mutation that reduce AT III ability to bind with heparin. In the last two types, AT III activity may be in normal limits. ${ }^{10}$ Therefore, deficiency of AT III can not be ascertained solely from activity level.

This study showed that deficiency of protein S, protein C, and AT III did not related to DVT. This was different from other studies that showed correlation between the deficiencies with DVT formation. This fact might be due to the categorization. In this study, categorization of deficiencies was in semiquantitative data, more over, the number of positive DVT samples were not equal to the negative ones. The other 
possibility was that the deficiency of protein S, C, and AT III individually did not influence DVT formation. The presence of two or more factor of thrombophilia may give more influence in promoting DVT. In the subjects with negative DVT, the low activity level of protein $\mathrm{C}, \mathrm{S}$, and AT III might be effective to inactivate coagulation factors.

Hyperfibrinogenemia did not correlate significantly to DVT. However, hyperfibrinogenemia have high attributable risk for DVT. The fact was due to limited sample. Fibrinogen is the acute phase reactant protein. Fibrinogen synthesis is keyed to stimulation by interleukins during inflammation, infection, or malignancy. During severe stress or fibrinogen breakdown, the turnover rate (normally 3 to 5 days) may increase 25 fold. ${ }^{19}$ Fibrinogen increases fibrin formation, thrombocyte aggregation, and plasma viscosity. ${ }^{12,20}$ In the acute phase, other factors play a role in the elevation of the fibrinogen level, such as age, gender, race, smoking, and obesity. Nevertheless, in this study, hyperfibrinognemia did not correlate to gender, age, and obesity.

In this study, factors that influence DVT formation, such as diabetes mellitus, hypertension, hypercholestrolemia, hypertrigliseridemia, obesity, and age did not correlate to DVT. Endothelial damage and hypercoagulability may play more role in DVT formation, than venous stasis.

In conclusion, the incidence of post orthopedic surgery DVT in this study was 25\%. Hyperfibrinogenemia was found to be a factor to promote DVT post high risk orthopedic operation. Deficiency of protein S, C, and AT III had no significant role in causing DVT. The other factors that were believed to influence DVT formation such as diabetes mellitus, hypertension, hypercholestrolemia, hypertrigliseridemia, and obesity had no significant correlation to DVT.

Suggestion: Evaluation on thrombophylia factors, especially fibrinogen, is suggested to patient who are planned to undergo high risk orthopedic surgery, and if there are hyperfibrinogenemia or two or more factors of thrombophylia, thrombophylia prophylaxis is recommended. Respective study on thrombophylia and DVT with ideal sample size, study of DVT incidence, multicenter study, the use of DVT prophylaxis, and respective study on clinical progress, complication, and evaluation of post operative DVT patients are still needed.

\section{Acknowledgment}

Special thanks to Dr. Ifran Saleh, SpBO for allowing his patients to be included in this study. We also thank the Sanofi-Synthelabo, Indonesia, for supporting part of the study, Dr. Jacub Pandelaki, Sp.Rad from department of Radiology, and staff of the Laboratory of Thrombosis Hemostasis, Department of Internal Medicine, FMUI/RSCM for their generous cooperation, and finally, Dr Shuffrie Effendi SpPD for statistical analysis correction.

\section{REFERENCES}

1. Hirsh J, Hoak J. Management of deep vein thrombosis and pulmonary embolism. Circulation 1996;93:2212-45.

2. Ciccone II WJ, Pellegrini VD. Deep venous thrombosis after total knee arthroplasty. Comp Orthop 1996; 11(4):1115. Available from: URL: http://www.medscape.com.

3. Jusi HD. Kelainan system vena. In: Jusi HD, Editor. Dasardasar ilmu bedah vaskuler. $2^{\text {nd }}$ ed. Jakarta:FKUI;1999.p.153-8.

4. Weinmann EE, Salzman EW. Deep vein trombosis. N Engl J Med 1994; 331(24):1630-9.

5. Hussain S, Schwartz JM. Pathogenesis, prevention and treatment of arterial and venous thrombosis. In: Friedman $\mathrm{S}$, editor. Vascular disease: a concise guide to diagnosis, management, pathogenesis, and prevention. Boston: John Wright; 1982. p.359-76.

6. Burroughs KE. New consideration in the diagnosis and theraphy of deep vein thrombosis. South Med J 1999; 92(5):517-20. Available from: http://www.medscape.com.

7. Paiement GD. TVD prophylaxis-TVDc prophylaxis after total joint arthroplasty. Medscape Orthopaedics \& Sports Medicine 1998; 2(6):1-9. Available from: URL : http://www.medscape.com.

8. Abramson N, Abramson S. Hypercoagulability: clinical assessment and treatment. South Med J 2001; 94 (10) : 1013-20. Available from:URL:

http://www.medscape.com/viewarticle/415086.

9. Rees DC, Clegg JB, Cox M. Wordl distribution of factor V leiden. The Lancet 1995; 346: 1133-4.

10. Ismail D, Harun S, Alwi I, Tambunan KL, Effendy S. Anti-thrombin III, Protein C, and Protein S deficiency in acute coronary syndrome. Med J Indones 2002;11: 8792.

11. Stecc U, Sibershatz H, Tofler GH. Association of fibrinogen with cardiovascular risk factors and cardiovascular disease in the Framingham off spring population. Circulation 2000;102:1634-8.

12. Leclerc JR. TVD prophylaxis-pharmacologic prophylaxis and treatment of venous thromboembolism after lower extremity arthroplasty. Medscape Orthopaedics \& Sports Medicine 1998. Available from :URL :

http://www.medscape.com.

13. Aaron RK, Ciombar D. Venous thromboembolism in orthopedic patient. Surgical Clinics of North America $1983 ; 63: 529-37$. 
14. Dhillon KS, Askander A, Doraisamy S. Postoperative deep-vein thrombosis in asian patients is not a rarity. The $\mathbf{J}$ Bone Joint Surg 1996;78-B:427-30.

15. Wang E. The Incidence of TVD among Filipinos undergoing high risk orthopedic surgery. Symposium in Deep Vein Thrombosis. Jakarta, $21^{\text {st }}$ April 2001.

16. Lonner JH. Thromboembolic disease in total knee arthroplasty diagnosis and overview. Am J Knee Surg 1999; 12;1:43-8.

17. Rhee R, Gloviczki P, Mendonca CT. Mesenteric venous thrombosis still a lethal disease in the 1990s. J Vasc Surg 1994;20:688-97.
18. Svenson PJ, Dahlback B. Resistance to activated protein C as a basic for venous thrombosis. N Engl J Med 1994; 330(8):517-22.

19. Goodnight SH, Hathaway WE. Disorders of hemostasis and thrombosis. $2^{\text {nd }}$ ed. New York: McGraw-Hill; 2001.

20. Simmonds RE, Hermida J, Rezende SM. Haematology genetic risk factor in arterial thrombosis. Blood 2001;86:374-85. 